Neffati, A., Khiari, W., \& Lajmi, A. (2020). Corporate governance and post-merger performance: evidence from US banks. Copernican Journal of Finance \& Accounting, 9(3), 99-113. http://dx.doi. org/10.12775/CJFA.2020.014

\author{
Amira Neffati* \\ GEF-2A Laboratory, University of Tunis \\ WIDED KHIARI ${ }^{* *}$ \\ GEF-2A Laboratory, University of Tunis \\ AzHAAR LAJMi** \\ GEF-2A Laboratory, University of Tunis
}

\title{
CORPORATE GOVERNANCE AND POST-MERGER PERFORMANCE: EVIDENCE FROM US BANKS
}

Keywords: bank mergers, governance, bank performance, deficit ratio.

\section{J E L Classification: G32, G34, G21.}

Abstract: Mergers operations has currently become one of the key strategies for many firms. It becomes a tool to increase firm value when firm has reached its peak performance. This critical decision expects business performance to improve.

Date of submission: August 3, 2020; date of acceptance: October 4, 2020.

* Contact information: neffati.emira@gmail.com, Institut Supérieur de Gestion, 2000, Le Bardo, University of Tunis, Tunisia, phone: +216-29006858; ORCID ID: https:// orcid.org/0000-0002-3764-8447.

** Contact information: khiariwided@yahoo.fr, Institut Supérieur de Gestion, 2000, Le Bardo, University of Tunis, Tunisia, phone: +216-98586639; ORCID ID: https://orcid. org/0000-0001-7248-2780.

*** Contact information: azhaar_lajmi@yahoo.fr, Institut Supérieur de Gestion, 2000, Le Bardo, University of Tunis, Tunisia, phone: +216-53958536; ORCID ID: https://orcid. org/0000-0002-7841-8402. 
The main purpose of this study is to analyze the impact of various governance variables, like managerial ownership, the percentage of shares held by outside directors, the board size, the audit committee size and the percentage of stock options granted to managers, on post merger banks performance and to investigate how the firm size can influence bank performance following mergers operations. It also tends to test the existence of the phenomenon of Empire building which is defined as a primary motivation for mergers operations. Empirical analysis is based on a panel data model applied to a sample of 54 banks come from the list of U.S. bank mergers over a period of 6 years from 2009 to 2015.

Our results show that the increase in managerial ownership decreases the value of the deficit, therefore, improves the bank performance following mergers operations. The introduction of firm size shows that this variable is positively correlated with the value of the deficit that is used as a performance measure in this study.

Our results converge with previous studies that show an improvement in the performance following bank mergers.

\section{INTRODUCTION}

The shareholders who are potentially harmed by the development of the agency theory, have established a set of control mechanisms allowing leaders to discipline and limit the extent of their authority so they can manage the firm based on their goals. This set of mechanisms is included under the term of the theory of corporate governance and is known since the 90's continuous development. According to Shleifer and Vishney (1997), this theory is the means by which the fund providers ensure a sufficient return on their investments. Thus, corporate governance aims to define the powers that influences the decisions of leaders and govern their behavior. It is in this sense that Jensen and Meckling (1976) and more recently Attari and Banerjee (2000) showed that property managers can align their interests with those of shareholders. Finally, and in order to maximize the firm value, Jensen and Murphy (1990) proposed to use the compensation related to the value of the firm to ensure the alignment of interests of managers with those of shareholders.

In this context, the impact of governance variables on bank performance following mergers operations has been widely investigated in financial literature. We first address the relationship between managerial ownership and bank performance. In fact, the accelerated number of bank mergers in the world and the increasing importance given to the relationship between agency problems and possibilities of success of these operations, have attracted the attention of several researchers. Their studies have been conducted to assess the relationship between managerial ownership and bank performance more precisely be- 
tween the ownership of internal operations and the effect of takeover on the bank performance. The findings on this subject are many and vary according to the type of performance measures used, for instance, accounting or market measures, and it is still difficult to demonstrate an improvement in bank profitability following mergers operations. According to the several empirical studies, experts and researchers are all in agreement that mergers and acquisitions can only lead to a very modest improvements in the efficiency of firms. Based on these studies, we note that mergers rarely lead to improve the firm performance. Statistics show that only $15 \%$ to $20 \%$ of U.S. mergers can be qualified as successful. Several researchers have studied the relationship between the outsiders, the board size and performance. These studies have shown a positive relationship between the director independence, the small size of the board and the effective control of the Board (Peasnell, Pope \& Young, 1998). For their part, the study of Brickley, Coles and Terry (1994) found significant high yields at the announcement of a takeover in case of a small sized board of directors that is dominated by outside directors. Peasnell et al. (1998) showed that the relationship between managerial ownership and the number of outsiders in the board of directors is a relationship that takes the form of $U$. This nonlinear relationship can be explained by using a combination of assumptions alignment of interest and rooting. According to Kartal, Ibis and Catikkas (2018), the audit committee is important in terms of performing efficiently and effectively, protecting assets, supervisiong the preparation of the reliable financial reporting of banks, and so can affect positively their performance. A big enough and active audit committee can positively influence the performance and increase the probability of neutralization of any attempt at the management by managers and reduce probability of fraud. In this sens, agency theory suggests that well-governed firms (by board of directors, audit committee) perform relatively better than their poorly-governed counterparts (Zhou, Ansah \& Maggina, 2018). Compensation plans are intended to align the interests of managers with those of shareholders. Benston (1985) in their studies have shown that the change in the level of compensation is positively related to the changes in stock prices. Despite the multitude of research that focused on the relationship between compensation and managerial performance, only few of them have tried to study this relationship in the context of a takeover transaction, especially mergers.

The aim of this paper is twofold. The first object is to study the impact of corporate governance characteristics, like managerial ownership, the percent- 
age of shares held by outside directors, the board size, the audit committee size and the percentage of stock options granted to managers, on performance due to bank mergers. The second one is to analyze the relevance of these variables and how they can increase the firm's value.

The rest of the paper is organized as follows. The first part provides an overview of mergers operations in the U.S. banking industry in the post-2000 period. It also includes a literature review on bank mergers. The second part discusses sample selection and provides descriptive statistics of the sample and bank performance characteristics.

\section{OVERVIEW OF MERGERS OPERATIONS IN THE U.S. BANKING INDUSTRY}

Mergers and acquisitions (M\&A) has always been an issue for managers and financial analysis. Number of studies have been conducted in order to address the effects of M\&A on firm performance (Dutescu, Ponorica \& Stanila, 2013). Most of them use financial variables such as return on assets, return on capital, total assets ratio, return on net worth, operational profit margin as their research variable. For our case, we propose a new financial indicator that allows us to assess the effect of mergers operations on firms financial performance.

The number of US banks has decreased from around 14.500 in the mid1980 s to 5.600 today for many reasons. Since the end of the 2007-2009 crisis, voluntary meltdowns have been the main cause of the decline and, although the reasons for the merger are potentially different, the transaction is assessed and may result in a denial. For example, according to Adams (2012), the use of Pilloff's and Rhoades's methods to account for mergers would result in significantly fewer mergers between 2008 and 2010 because, in those years, a number of failure-related mergers took place.

In fact, the financial crisis has shaped consolidation activities in the US market with a decline in the number of transactions, as well as an evolution of mergers and acquisitions to institutions in difficulty (Adams, 2012). By way of illustration, the number of banks that was eliminated by mergers activity decreased by $26 \%$ from 2.272 banks between 2000 and 2006 to 1.695 banks between 2007 and 2012.

Between 2000 and 2010, 2,403 mergers took place. On average, every year 218 mergers occured, with a minimum of 158 in 2009 and a maximum of 259 in 2004 , with the exception of 2008, 2009 and 2010, where we can note a slightly 
decrease to reach 195, 158 and 180 mergers respectively. Before 2000, mergers were much larger, with more than 440 mergers, on average, from 1994 to 1999.

The decline that began in August 2007 contributed to the observed decline in the number of mergers transactions. The types of transactions have changed considerably over these years. The years 2008 and 2009 were marked by a significant increase in the number of transactions involving failed or failing institutions. These two years have been also marked by a dramatic decrease in the number of standard acquisitions. Particularly, two years were remarkable in the volume of merger activity: 2001 and 2004. In each of these years, the averages and percent industry in each category were well above levels in other years.

Althought, the year 2015 witnessed the largest number and the biggest of merger and acquisition transaction, which increased by $42 \%$ over the 2014 figures, to a new high of US $\$ 4.7$ trillion. The year 2015 was also the strongest year for merger activity since 1980 .

Many papers have dealt with bank mergers over the last 50 years. Pilloff (2004) investigates mergers from 1994 to 2003. Wheelock (2011) study mergers during the 2007 financial crisis to 2010.

These papers differ in their data sources on bank mergers and how they count for bank mergers, and many of them identify post-merger performance improvements for mergers with certain transaction characteristics (Hagendorff \& Keasey, 2009). Other researches examine the pre-merger characteristics of target and acquiring banks, and identifies changes in operating efficiency, as well as the trend of mean reversion in the post-merger period (AlSharkas, Hassan \& Lawrence, 2008). However, until this date many studies, focus on M\&As occured in the post financial crisis period of 2007-2009, a period with high systemic risk and financial instability, without taking into account the special characteristics of this period.

In addition, previous researches in the 2000 s based on earlier literature and examining additional measures of corporate performance, have tried to assess post-merger performance using various factors, but identify inconsistent results in the US banking sector prior to the financial crisis years 2007-2009. That is why we try in this work to contribute to previous studies by identifying any differences in post-mergers during the post-financial crisis period, using a new financial performance measure called the "deficit ratio" to evaluate the post-merger performance of US banks, particularly in the post financial crisis period of 2007-2009 and compare our results with those of other studies that failed to reach consensus on this issue. 


\section{RESEARCH METHODOLOGY AND RESEARCH PROCESS}

\section{Sample Selection}

The governance variables used in this study are the percentage of managerial ownership, the percentage owned by outside directors and the percentage of stock options granted to managers. Data were collected from firms' proxy statement reports and annual reports from the EDGARSCAN website. Our sample excluded firms that have no available reports. 54 banks come from the list of U.S. bank mergers, published by the Federal Reserve Bank are used to study the influence of corporate governance variables on the banking performance following mergers operations over the period 2009-2015.

\section{Descriptive statistics analysis}

Results from descriptive statistics of governance variables are summarized in table 1.

Table 1. Descriptive statistics

\begin{tabular}{|l|c|c|c|c|c|}
\hline \hline & N & Minimum & Maximum & Mean & SD \\
\hline \hline Insiders & 54 & 0.15 & 27.12 & 3.0409 & 4.92244 \\
\hline Outsiders & 54 & 0.01 & 15.65 & 2.8580 & 3.49104 \\
\hline Stock option granted & 54 & 0.02 & 2.39 & 0.2351 & 0.45606 \\
\hline \hline
\end{tabular}

S o u r c e : own study.

These statistics show that the average managerial ownership of banking firms is 3.0409 which is less than $5 \%$ (Only six banks have a percentage of managerial ownership that exceeds $5 \%$ ). The average of 2.858 indicates a significant presence of outside directors in banking firms in our sample. All the banking firms in our sample have a remuneration system that is interlinked with the stock market performance with an average of $2.39 \%$. 


\section{RESULTS AND DISCUSSION}

\section{Deficit Ratio: Study and interpretation}

The deficit ratio is a variable that can measure the performance arising from bank mergers. In the following research, we have adopted this ratio mainly in order to study the influence of various governance variables on the banking performance after mergers.

Based on the study of Hughes, Lang, Mester, Moon and Pagano (2002), the deficit ratio specification is as follows:

Deficit ratio $=\alpha_{0}+\alpha_{1}$ internals $+\alpha_{2}$ (internals $)^{2}+\alpha_{3}$ externals $+\alpha_{4}(\text { external })^{2}$ $+\alpha_{5} \log$ board size $+\alpha_{6} \log$ (Audit committee size) $+\alpha_{7} \log$ (audit committee meetings) $+\alpha_{8}$ options granted $+\alpha_{9}$ (options granted) ${ }^{2}+\alpha_{10}$ (internals ${ }^{*}$ options granted)

More precisely, the firm performance is calculated through the deficit ratio which reflects the difference between boundary value and market value. $\mathrm{Nu}$ merically, the model is formulated as follows:

Deficit ratio of bank $i=$ the value of the deficit of the bank $i$ / market value achieved of bank $i$

With,

The value of the deficit of the bank $i=$ boundary value ${ }^{1}-$ market value achieved

For this purpose, we carried out a linear least squares regression that delivered the results shown in table 2 .

1 The boundary value is measured by the technique of stochastic frontier (Jondrow, Lovell, Materov \& Shmidt, 1982). 
Table 2. Results from Deficit Ratio

\begin{tabular}{|c|c|c|}
\hline \multirow{2}{*}{ Independent variables } & \multicolumn{2}{|c|}{ Dependent variables } \\
\hline & coefficient & t-statistic \\
\hline Internals & -0.694 & $-3.215^{* * *}$ \\
\hline$(\text { internals) })^{2}$ & -0.264 & -1.491 \\
\hline Externals & -0.214 & -0.816 \\
\hline$(\text { externals })^{2}$ & -0.323 & $-3.295^{* * *}$ \\
\hline options granted & -0.338 & $-2.015^{* *}$ \\
\hline (options granted) ${ }^{2}$ & -0.082 & -0.458 \\
\hline (internals*options granted) & -0.785 & $-3.802 * * *$ \\
\hline Board size & -0.719 & $-2.156^{* *}$ \\
\hline Audit committee size & -0.814 & $-2.017^{* *}$ \\
\hline Audit committee Meetings & -0.579 & $-2.401^{* *}$ \\
\hline 0.590 & & \\
\hline Adjusted & & \\
\hline
\end{tabular}

** Significant at $5 \%$ level of confidence, ${ }^{* * *}$ Significant at $1 \%$ level of confidence.

S o u r c e : own study.

The results of the regression indicate that the coefficient of insider ownership related to financial performance is negative and significant at a confidence level of $10 \%$ as measured by the deficit ratio. Thus, increasing the fraction of shares held by insiders reduces the deficit ratio. This is explained by the decrease of the gap between the value on the efficient frontier and the market value which therefore improves the financial performance of the bank.

Given these statistics, the output of the regression analysis found at the variable managerial ownership seems quite logical considering that one is in a range of alignment [0\%-5\%] as presented by Morck, Shleifer and Vishney (1988). In this interval, leaders will proceed according to the interests of the shareholders and will normally initiate mergers that increase the firm value.

The study of the interrelationship between the percentage of stock options granted to managers and the percentage of shares held by managers generates a significant and negative coefficient at a confidence level of $1 \%$. These results show that increasing the percentage of managerial ownership and the value of 
stock options decrease the ratio of deficit and consequently improves the performance of banks. This confirms the results found when comparing the relationship between the stock options and performance.

Indeed, the average of managerial ownership in our sample is 3.0619 and that may explain the results found at this level. A small percentage of managerial ownership aligns the interests of managers with those of shareholders and reduces agency costs for firms (Hermalin \& Weisbach, 1988; Morck et al., 1988). On one hand, the results of this study are similar to results found by Hermalin and Weisbach (1988) that affirmed a positive relationship, at low levels of ownership, between managerial ownership and firm performance. However, they contradict the predictions of Jensen and Meckling (1976) who found that with low levels of managerial ownership (less than 5\%) managers have little incentive to improve the value of the firm and therefore shareholder wealth and tend to expropriate the resources of the firm through overuse and sometimes unwarranted resources.

On the other hand, these results confirm that the relationship between managerial ownership and financial performance for banking firms is almost the same as for non-financial institutions despite the differences that exist within the agency problem between these two types of firms and the characteristics of banking firms regarding the accounting organization.

The results of the regression equation indicate that the coefficient on log of outsiders is negative and insignificant. However, the use of the square outside directors can detect a negative and significant coefficient at a confidence level of $10 \%$.

The square outside directors is used to verify the nonlinear relationship between the fraction of outsiders on the board of directors and financial performance (Brickley et al., 1994).

The results found in this study show that increasing the percentage of ownership held by outside directors decreases the deficit ratio, reduces the gap between the boundary value of the bank and its achieved market value which consequently improves the bank performance following mergers. This confirms the results found by several researchers like Hanson and Song (1997) that indicated that increasing the number of outsiders in the board of directors reduced the managerial opportunism and enhanced shareholder wealth. A positive and significant coefficient allows to assert that the size of the board of directors increases the value of deficit. 
Regarding the audit committee, the results show that the size and activity of this committee have a negative effect on the deficit value. This is consistent with previous findings in the literature (Carcello \& Neal, 2000) which affirm the idea that the characteristics of this committee improves performance.

In the rest of this paper, we will study the relationship between firm size and performance following bank mergers.

\section{Modified deficit Ratio: Study and interpretation}

In this section, we will study the impact of the increase in the firm size on banks performance following bank mergers. This impact will be measured by the modified deficit ratio. According to several researches, the existence of managerial incentives has initiate mergers in order to increase the firm size and therefore their compensation and not to improve the firm value. In this study, we extend these works by introducing the variable firm size measured by total assets. So, the new model is presented as follows:

Modified deficit ratio $=\alpha_{0}+\alpha_{1}$ internal $+\alpha_{2}$ (internal $)^{2}+\alpha_{3}$ external $+\alpha_{4}$ (exter$n a l)^{2}+\alpha_{5} \log$ board size $+\alpha_{6} \log$ audit committee size $+\alpha_{7} \log$ audit committee meetings $+\alpha_{8}$ options granted $+\alpha_{9}$ (options granted) $)^{2}+\alpha_{10}$ (internals ${ }^{*}$ options granted) $+\alpha_{11}$ Total assets $+\alpha_{12}$ (Total assets) ${ }^{2}+\alpha_{13}$ (Total assets * options granted)

This new formulation of the deficit ratio was noted by introducing the firm size variable that has been measured by the total assets. More precisely, the square variables total assets and the option granted is introduced to test the effect of the increase of these variables on performance as well as on the relationship between these variables. In this context, the square linear regression results are presented in table 3.

Table 3. Modified Deficit Ratio

\begin{tabular}{|l|c|c|}
\hline \multirow{2}{*}{\multicolumn{1}{c}{ Independent variables }} & \multicolumn{2}{|c|}{ Dependent variables } \\
\cline { 2 - 3 } & coefficient & t-statistic \\
\hline \hline Total assets & 3.172 & $3.475^{* * *}$ \\
\hline (total assets) & -4.313 & $-2.142^{* * *}$ \\
\hline
\end{tabular}


Table 3. Modified...

\begin{tabular}{|c|c|c|}
\hline \multirow{2}{*}{ Independent variables } & \multicolumn{2}{|c|}{ Dependent variables } \\
\hline & coefficient & t-statistic \\
\hline Total assets*options granted & 1.790 & $1.873^{*}$ \\
\hline Internals & -0.804 & $-3.785^{* * *}$ \\
\hline$(\text { internals) })^{2}$ & -0.310 & -1.678 \\
\hline Externals & -0.168 & -0.845 \\
\hline$(\text { externals) })^{2}$ & -0.348 & $-3.411^{* * *}$ \\
\hline options granted & -0.574 & $-2.234^{*}$ \\
\hline (options granted) $^{2}$ & -0.084 & -0.451 \\
\hline (internals*options granted) & -0.614 & $-3.521^{*}$ \\
\hline Board size & 0.746 & $-2.432^{*}$ \\
\hline Audit committee size & -0.838 & $-1.967^{*}$ \\
\hline Audit committee Meetings & -0.789 & $-2.457^{*}$ \\
\hline 0.414 & & \\
\hline Adjusted & & \\
\hline
\end{tabular}

${ }^{*}$ Significant at $10 \%$ level of confidence ** Significant at 5\% level of confidence *** Significant at $1 \%$ level of confidence.

S o u r c e : own study.

In this table, it is shown that the significance and sign of the coefficients of the governance variables did not change following the introduction of the variable firm size.

Results show that the total assets coefficient is positive and significant at a confidence level of $10 \%$. These results show that the total assets of the firm following the merger increases the deviation between the firm value and its performed market value and therefore deteriorate the firm performance. These results seem to be surprising and unexpected since they contradict those found by the governance variables (Morck et al., 1988). However, the use of the square of the total assets variable indicates a negative and significant coefficient at a confidence level of $5 \%$. This result indicates an improvement in performance due to the accumulation of assets in the firm. In order to highlight managerial incentives and increase the firm size, we added the variable (total 
assets*options granted). This variable will allow the study of interactions between the variable measuring the firm size and the managerial compensation presented in our study through the variable stock option granted and its impact on banking performance.

The regression results indicate a positive and significant coefficient at a confidence level of $10 \%$. The coefficient generated by the regression equation shows that increasing the percentage of stock options due to an increase in firm size increases the deviation between the boundary value and the market value by the bank. This increase results in a deterioration of the value of the firm and affects the wealth of shareholders. This result indicates that managers have incentives to increase the firm size and enjoy better compensation even if this negatively affects the firm value. Furthermore, the correlation matrix between firm size and ownership of internal is negative and significant. This contradicts the findings of Jensen (1986) stating that managers are looking to increase the size of their firms to benefit from the prestige of leadership of large firms. Indeed, this result can be explained by the fact that banks in the sample are banks with low percentage of managerial ownership. So, banks that are in the range alignment [0\%-5\%] and whose managers operate in accordance with the interests of shareholders, are further to undertake mergers that destroy value.

\section{CONCLUSION OF THE RESEARCH PROCESS}

The purpose of this paper is to examine the impact of governance variables on performance following bank mergers. Initially, we focused on studying the relationship between managerial ownership and the deficit ratio. The regression analysis indicates a positive relationship between these two variables. Indeed, the managerial ownership improves firm performance. Then, the results argue that an increase in the percentage of this property reduces the deviation between the achieved boundary value and market value and therefore creates the value for the banking firm.

Regarding the board size, it is positively correlated to the ratio of the deficit. So an increase in the number of board members decreases the performance of the bank following mergers. However, an active and large audit committee enhances bank performance following mergers operations. Then we discussed the third variable governance, which is managerial compensation. It is shown 
in this work by the percentage of stock options granted to managers. This form of compensation is linked to the market value of the firm. The empirical result indicates an improvement in banking performance through the award of such shares to managers. The last part of this article was devoted to the study of the effect of increasing the asset size and performance in order to test the existence of the phenomenon of empire building. In presence of this phenomenon, managers initiate mergers operations that destroy value just for the prestige of managing larger firms and have a better compensation. The results indicate that firm size is negatively related to performance. However, using the square of the variable total assets gives us opposite results indicating that an increase in bank assets improves performance and denounces the existence of the phenomenon of empire building.

Finally, the results found in this study indicate an improvement in the performance following bank mergers as supported by many other researches (Hagendorff \& Keasey, 2009). But it also must be considered that merger in itself is not the ultimate solution to strengthen the financial position of banks. A lot of factors, related to the specifities of the banks, must be taken into account before finding the right partener to merger with and executing the merger. But it's also observed, in many previous researches, that merger may not have positive impact on performance. This can be explained mainly by the specificity of the study sample. As all research works, our article presents some limits related to the sample used. The latter is relatively small wich provides an opportunity to other studies to take larger sample for better results. Finally, results can serve as a basis for policy makers and scholars alike.

\section{REFERENCES}

Adams, R.M. (2012). Consolidation and Merger Activity in the United States Banking Industry from 2000 through 2010. Washington DC : The Federal Reserve Board.

Al-Sharkas, A.A, Hassan, M.K., \& Lawrence, S. (2008). The impact of mergers and acquisitions on the efficiency of the US banking industry: further evidence. Journal of Business Finance and Accounting, 35(1-2), 50-70. http://dx.doi.org/10.1111/j.14685957.2007.02059.x.

Attari, M., \& Banerjee, S. (2000). Strategic underinvestment: managerial entrenchment and the ownership structure of firm. Working Paper SSRN. http://dx.doi. org/10.2139/ssrn.135718.

Benston, G. J. (1985).The Validity of Profits-Structure Studies with Particular Reference to the FTC's Line of Business Data. American Economic Review, 75(1), 37-67. 
Brickley, J.A., Coles, J.L., \& Terry, R.L. (1994). Outside directors and the adoption of poison pills. Journal of Financial Economics, 35(3), 371-390. http://dx.doi. org/10.1016/0304-405X(94)90038-8.

Carcello, J.V., \& Neal, T.L. (2000). Audit committee characteristics and auditor reporting. Working Paper SSRN. http://dx.doi.org/10.2139/ssrn.53917.

Dutescu, A., Ponorica, A.G., \& Stanila, G.O. (2013). Effects of mergers and acquisitions on financial performance of the target company. Challenges of the Knowledge Society. Finance and Accounting.

Hagendorff, J., \& Keasey, K. (2009). Post-merger strategy and performance: Evidence from the US and European banking industries. Accounting and Finance, 49(4), 725-751. http://dx.doi.org/10.1111/j.1467-629X.2009.00306.x.

Hanson, R.C., \& Song, M.H. (1997). Managerial ownership, Board Structure and the Division of Gains in Divestitures. Working Paper SSRN.

Hermalin, B., \& Weisbach, M.S. (1988). The determinants of board composition. RAND Journal of Economics, 19(4), 589-606.

Hughes J.P., Lang, W., Mester, L.J., Moon, C.G., \& Pagano, M.S. (2002). Do bankers sacrifice value to Build Empire? Managerial incentives, Industry Consolidation, and Financial Performance. FRB of Philadelphia Working Paper, 02-2. http://dx.doi.org/10.2139/ ssrn.314574.

Jensen, M.C. (1986). Agency cost of free cash flow, corporate finance, and takeovers. American Economic Review, 76(2), 323-329. http://dx.doi.org/10.2139/ssrn.99580.

Jensen, M.C., \& Meckling, W.H. (1976). Theory of the firm, managerial behaviour, agency costs and ownership structure. Journal of Financial Economics, 3(4), 305-360. http:// dx.doi.org/10.1016/0304-405X(76)90026-X.

Jensen, M.C., \& Murphy, K.J. (1990). Performance pay and top management incentives. Journal of Political Economy, 98(2), 225-264. http://dx.doi.org/10.1086/261677.

Jondrow, J., Lovell, C.A., Materov, I.S., \& Shmidt, P. (1982). On the estimation of technical efficiency in the stochastic frontier production function model. Journal of Econometrics, 19(2-3), 233-238. http://dx.doi.org/10.1016/0304-4076(82)90004-5.

Kartal, M.T., Ibis, C., \& Catikkas, Ö. (2018). Adequacy of audit committees : A study of deposit banks in Turkey'. Borsa Istanbul Review, 18(2), 150-165. http://dx.doi. org/10.1016/j.bir.2018.01.002.

Morck, R., Shleifer, A., \& Vishney, R.W. (1988). Management ownership and market valuation: An empirical analysis. Journal of Financial Economics, 20, 293-315. http:// dx.doi.org/10.1016/0304-405X(88)90048-7.

Peasnell, K.W., Pope, P.F., \& Young, S. (1998). Managerial ownership and the demand for outside directors. Working Paper Lancaster University.

Pilloff, S.J. (2004). Bank Merger Activity in the United States, 1994-2003, Staff Study 176. Washington: Board of Governors of the Federal Reserve System.

Shleifer, A., \& Vishney, R.W. (1997). A survey of corporate governance. Journal of Finance, 52(2), 737-783. http://dx.doi.org/10.1111/j.1540-6261.1997.tb04820.x. 
Wheelock, D.C. (2011). Banking Industry Consolidation and Market Structure: Impact of the Financial Crisis and Recession. Federal Reserve Bank of St. Louis Review, 93, 419-438.

Zhou, H., Ansah, O.S., \& Maggina, A. (2018). Board of directors, audit committee, and firm performance: Evidence from Greece. Journal of International Accounting, Auditing and Taxation, 31, 20-36. http://dx.doi.org/10.1016/j.intaccaudtax.2018.03.002. 